\title{
Chloroplast DNA recognizes three refugial sources of European oaks and suggests independent eastern and western immigrations to Finland
}

\author{
C. FERRIS*, R. A. KING, R. VÄINÖLÄ† \& G. M. HEWITT‡ \\ Department of Biology, University of Leicester, University Road, Leicester LE1 7RH, U.K., †Zoological Museum, \\ Finnish Museum of Natural History, P.O.B. 17, FIN-00014 University of Helsinki, Finland and $₫$ School of Biological \\ Sciences, University of East Anglia, Norwich NR4 7TJ , U.K.
}

\begin{abstract}
Refugial differentiation and routes of postglacial migration are major determinants of the patterns of geographical variation we see in natural populations today. We used patterns of chloroplast DNA (cpDNA) variation to investigate the postglacial colonization history of the European oak species Quercus robur and Q. petraea. By sequencing two cpDNA segments using universal primers, we revealed four polymorphic sites which identify four cytotypes with characteristic geographical distributions. Of these, the principal eastern, central and western cytotypes divide the range into three longitudinal zones, each extending from the south to the north of Europe. This corroborates the idea that the postglacial colonization started from three distinct southerly refugia. The fourth cytotype, restricted to East Anglia, was probably derived from the western type postglacially. As a special problem, we addressed the controversial origin of $Q$. robur at its northern limits in south-western Finland, where it currently occupies a narrow coastal zone disjunct from the remaining oak range. Using a PCR-RFLP assay that discriminates the eastern cytotype, a contact zone of two cytotypes was identified in the region of the Salpausselkä ridges. This suggests that the marginal northern occurrence was independently colonized both from the east and from the west, across the Baltic Sea.
\end{abstract}

Keywords: chloroplast DNA (cpDNA), genetic markers, postglacial migration, Quercus spp., $t R N A^{\text {Leul }}$ intron.

\section{Introduction}

During the major Pleistocene glaciations temperate forest species were restricted to refugial populations in the south of Europe. Such refugia are well documented for species with a good fossil pollen record, and occurred primarily in Spain, Italy and the Balkans (Huntley \& Birks, 1983; Bennett et al., 1991). The periods of isolation allowed genetic differentiation of the populations. The present patterns of marker distribution across Europe retain traces of the location and the numbers of refugia, and of the routes of northward expansion from these refugia following the climatic amelioration at the end of the last ice age.

The generally slow rate of cpDNA sequence evolution previously tended to discourage its use as

*Correspondence. E-mail: cf12@leicester.ac.uk a marker at lower systematic levels (Banks \& Birky, 1985; Palmer, 1987). However, recent population studies have revealed intraspecific geographical structuring of cpDNA (e.g. Doyle et al., 1990; Novak \& Soltis, 1991; Lavin et al., 1992), and there are a number of studies where the phylogeographical variation has been related to postglacial history; in the Saxifragaceae (Soltis et al., 1989, 1991, 1992), in European oaks (Ferris et al., 1993; Petit et al., 1993, 1996) and in the tulip tree (Sewell et al., 1996).

Quercus robur L. and Q. petraea (Matt.) Liebl. are widespread European oak species which frequently hybridize when sympatric. A genetic east/west division in both taxa has been documented using allozyme and cpDNA characters (Ferris et al., 1993; Petit et al., 1993, 1996; Zanetto \& Kremer, 1995). The eastern and western oak cpDNA cytotypes have been recognized on the basis of a single base substitution, which is identifiable by a restriction enzyme 
assay. These cytotypes most probably represent lineages derived from distinct southern refugia (Ferris et al., 1993). A contact zone of the two types runs south to north through Austria/Switzerland and Germany/Poland (Ferris et al., 1993). The cytotype distribution to the north has so far been poorly explored, but it seems logical that the western type has spread through Denmark to southern Scandinavia (Sweden), whereas the eastern type colonized the areas south and east of the Baltic Sea.

At the northern limits of its distribution $Q$. robur in Finland is currently restricted to a narrow zone in the south-western part of the country, facing the Baltic Sea (Hultén, 1971). This area is disjunct from stands connected to the eastern continental distribution in Russia. It has been suggested that the current Finnish range was initially colonized from the west, from Sweden across the Baltic Sea and was probably continuous to the east across southern Finland (e.g. Cajander, 1921; Skult, 1965). Alternatively, an initial spread from the east also seems conceivable, as during the climatic optimum, oak distribution extended further north, and was probably continuous across southern Finland (Donner, 1995). In light of the data of Ferris et al. (1993) the chloroplast marker now should provide an efficient tool to resolve the origin of the Finnish oak.

This study addresses two aspects of the divergence and distributional history of European oaks. As a particular problem, we explored the regional colonization history and presence of a contact zone in the northern reaches of the range in Finland, using the simple RFLP marker. At a more general level, we have sought for further resolution in the refugial history of oak chloroplast lineages by sequencing 875 bp of cpDNA in a number of samples throughout Europe.

\section{Materials and methods}

A total of 47 mature oaks (40 Q. robur, seven Q. petraea), collected from 42 sites representing 19 countries across Europe, were used for a DNA sequencing study (Fig. 1, Table 1). Six additional Quercus species were sequenced as outgroups: $Q$. cerris, $Q$. coccifera, $Q$. suber, $Q$. imbricaria, $Q$. wislizenii, and $Q$. pubescens.

In addition to the sequencing survey, 166 Q. robur trees from the northern parts of the range were assayed with a restriction digestion analysis. This
Fig. 1 Distributions of the four cytotypes determined by cpDNA sequencing (Table 3) in European samples of Quercus robur (circles) and Q. petraea (squares). Sample site details are given in Table 1. Symbol size is proportional to the number of individuals studied.

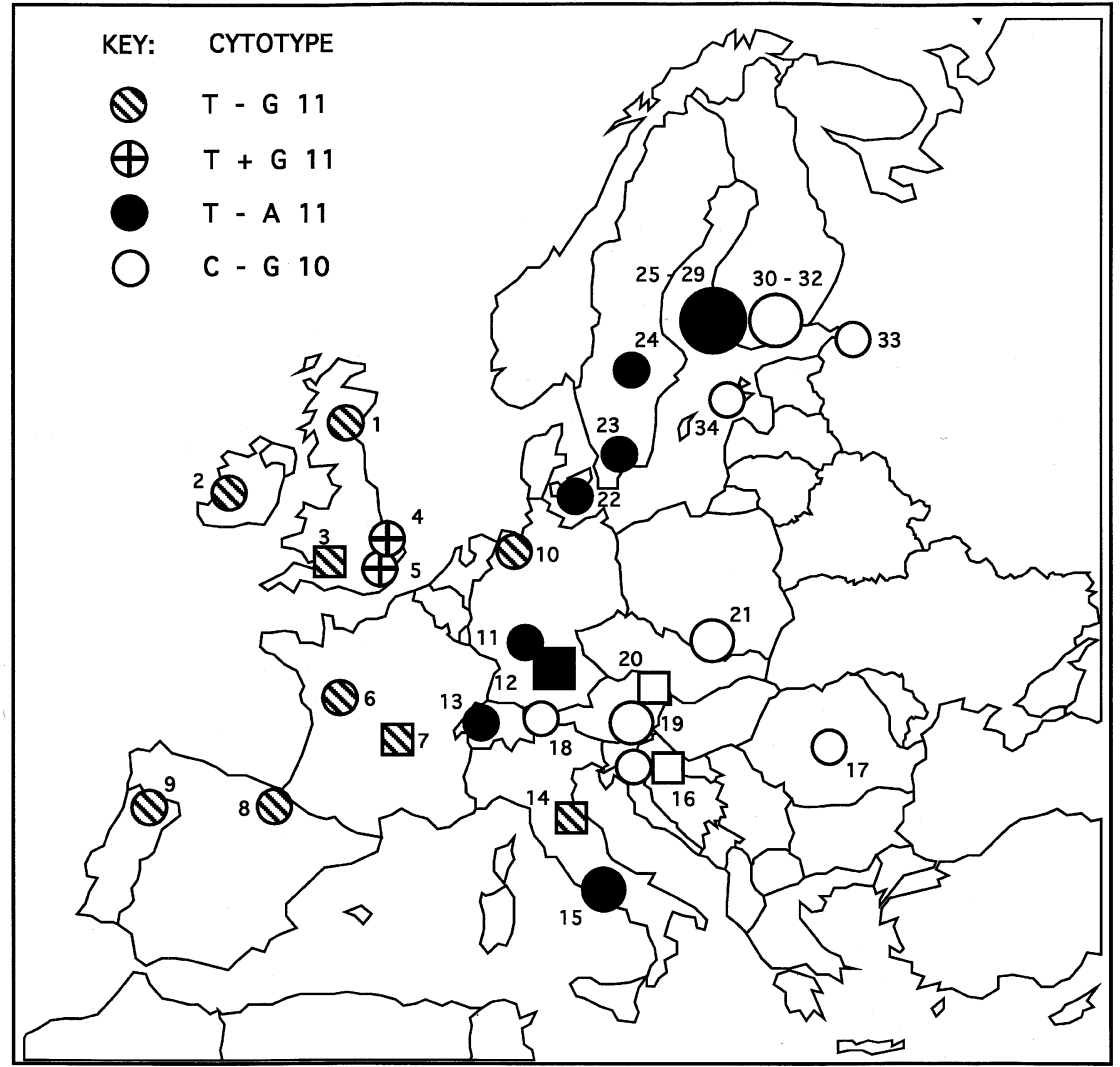


survey comprised 48 sites through the natural distribution of oak in southern Finland and the Aland Islands, and a number of samples from neighbouring regions in Sweden and north-west Russia (Fig. 2, Table 2). The Finnish and Swedish sites were chosen to most likely represent native stands, and this should also hold for at least two of the Russian samples.

Fresh leaf samples were frozen for storage. Total genomic DNA was extracted using the CTAB method of Doyle \& Doyle (1990), with minor modifications by Howland (1992). Two fragments from the Large Single Copy region of the chloroplast genome were PCR-amplified using the universal primers of Taberlet et al. (1991): the $t R N A^{\text {Leul }}$ intron (558 bp) and the nontranscribed intergenic spacer (IGS) between the $t R N A^{\text {Leul }}$ and $t R N A^{\text {Phe }}$ genes (381 bp). Reaction conditions were as given in Ferris et al. (1993).

Double-stranded PCR product was purified using QIAquick spin columns (Qiagen). DNA sequencing was performed on an ABI automated DNA sequencer (Perkin Elmer) using ABI PRISM dye deoxy chain terminator cycle sequencing. Sequencing reactions were performed in a total reaction volume of $20 \mu \mathrm{L}$ containing: double-stranded PCR product

Table 1 European samples of Quercus robur $(r)$ and $Q$. petraea $(p)$ given in Fig. 1. All samples have been sequenced for the $t R N A^{\text {Leul }}$ intron and the nontranscribed intergenic spacer between exon 2 of the $t R N A^{\text {Leul } 1}$ gene and $t R N A^{\text {Phe }}$ gene, and their cytotype based on four polymorphic positions is given

\begin{tabular}{|c|c|c|c|c|c|}
\hline No. & Site & Country & Species & $\begin{array}{c}\text { Sample } \\
\text { size }\end{array}$ & Cytotype \\
\hline 1 & Birnam & Scotland & $r$ & 1 & $\mathrm{~T}-\mathrm{G} 11$ \\
\hline 2 & Burren & Ireland & $r$ & 1 & $\mathrm{~T}-\mathrm{G} 11$ \\
\hline 3 & Powick Hams & England & $p$ & 1 & $\mathrm{~T}-\mathrm{G} 11$ \\
\hline 4 & Flordon & England & $r$ & 1 & $\mathrm{~T}+\mathrm{G} 11$ \\
\hline 5 & Thorpe Morieux & England & $r$ & 1 & $\mathrm{~T}+\mathrm{G} 11$ \\
\hline 6 & Poitiers & France & $r$ & 1 & $\mathrm{~T}-\mathrm{G} 11$ \\
\hline 7 & Tronçais & France & $p$ & 1 & $\mathrm{~T}-\mathrm{G} 11$ \\
\hline 8 & Ultzama & Spain & $r$ & 1 & $\mathrm{~T}-\mathrm{G} 11$ \\
\hline 9 & Montalegre & Portugal & $r$ & 1 & $\mathrm{~T}-\mathrm{G} 11$ \\
\hline 10 & Hasbruch & Germany & $r$ & 1 & $\mathrm{~T}-\mathrm{G} 11$ \\
\hline 11 & Bad Neuheim & Germany & $r$ & 1 & $\mathrm{~T}-\mathrm{A} 11$ \\
\hline 12 & Nidderau & Germany & $p$ & 2 & $\mathrm{~T}-\mathrm{A} 11$ \\
\hline 13 & Galm & Switzerland & $r$ & 1 & $\mathrm{~T}-\mathrm{A} 11$ \\
\hline 14 & Firenze & Italy & $p$ & 1 & $\mathrm{~T}-\mathrm{G} 11$ \\
\hline 15 & Rome & Italy & $r$ & 2 & $\mathrm{~T}-\mathrm{A} 11$ \\
\hline 16 & Zagreb & Croatia & $r / p$ & 2 & $\mathrm{C}-\mathrm{G} 10$ \\
\hline 17 & Stejar & Romania & $r$ & 1 & $\mathrm{C}-\mathrm{G} 10$ \\
\hline 18 & Styria & Austria & $r$ & 1 & $\mathrm{C}-\mathrm{G} 10$ \\
\hline 19 & Stamser & Austria & $r$ & 2 & $\mathrm{C}-\mathrm{G} 10$ \\
\hline 20 & Loretto & Austria & $p$ & 1 & $\mathrm{C}-\mathrm{G} 10$ \\
\hline 21 & Brzesko & Poland & $r$ & 2 & $\mathrm{C}-\mathrm{G} 10$ \\
\hline 22 & Skjoldenaesholm & Denmark & $r$ & 1 & $\mathrm{~T}-\mathrm{A} 11$ \\
\hline 23 & Markaryd & Sweden & $r$ & 1 & $\mathrm{~T}-\mathrm{A} 11$ \\
\hline 24 & Öglunda & Sweden & $r$ & 1 & $\mathrm{~T}-\mathrm{A} 11$ \\
\hline 25 & Orikvuori & Finland & $r$ & 1 & $\mathrm{~T}-\mathrm{A} 11$ \\
\hline 26 & Askainen & Finland & $r$ & 1 & $\mathrm{~T}-\mathrm{A} 11$ \\
\hline 27 & Luodonmaa & Finland & $r$ & 1 & $\mathrm{~T}-\mathrm{A} 11$ \\
\hline 28 & Katarinedal & Finland & $r$ & 1 & $\mathrm{~T}-\mathrm{A} 11$ \\
\hline 29 & Kurala & Finland & $r$ & 1 & $\mathrm{~T}-\mathrm{A} 11$ \\
\hline 30 & Gullö & Finland & $r$ & 1 & $\mathrm{C}-\mathrm{G} 10$ \\
\hline 31 & Espoo & Finland & $r$ & 1 & $\mathrm{C}-\mathrm{G} 10$ \\
\hline 32 & Sannäs & Finland & $r$ & 1 & $\mathrm{C}-\mathrm{G} 10$ \\
\hline 33 & Orekhovo & Russia & $r$ & 1 & $\mathrm{C}-\mathrm{G} 10$ \\
\hline 34 & Saaremaa & Estonia & $r$ & 1 & $\mathrm{C}-\mathrm{G} 10$ \\
\hline
\end{tabular}


$\approx 0.1 \mu \mathrm{g}, 8.0 \mu \mathrm{L}$ Terminator Ready Reaction mix, 3.2 pmole sequencing primer and distilled water. Reactions were overlaid with $40 \mu \mathrm{L}$ of mineral oil. The amplification in a Perkin Elmer Cetus 480 thermal cycler involved 25 cycles of denaturation $\left(30 \mathrm{~s}\right.$ at $\left.96^{\circ} \mathrm{C}\right)$, annealing $\left(15 \mathrm{~s}\right.$ at $\left.50^{\circ} \mathrm{C}\right)$ and extension $\left(4 \mathrm{~min}\right.$ at $60^{\circ} \mathrm{C}$ ) with a final soak at $4^{\circ} \mathrm{C}$. Sequenced products were then purified using ethanol precipitation before being vacuum-dried.

Restriction enzyme digestion of the $t R N A^{\text {Leul }}$ intron was performed on PCR products from all the 203 samples used in this study. The restriction enzyme $C f o$ I (Gibco) recognizes a pyrimidine transition polymorphism $(\mathrm{T} / \mathrm{C})$ at position 153 of the intron, as previously described by Ferris et al. (1993).

Forty-eight of the Fennoscandian samples were double-digested with $M b o \mathrm{I}$ and RsaI (Gibco) to detect the presence of the $13 \mathrm{bp}$ duplication within the $t R N A^{\text {Leu1 }}$ intron as described by Ferris et al. (1995).

\section{Results}

\section{Sequence survey across Europe}

Sequence comparisons involving a total of $875 \mathrm{bp}$ from the Leu1 intron and the intergenic spacer (IGS) revealed four polymorphic positions. Within the intron these include a pyrimidine transition $(\mathrm{C} / \mathrm{T})$ at position 153 and a 13-bp duplication at position $335(+/-)$. Within the IGS, a purine transition polymorphism $(\mathrm{A} / \mathrm{G})$ is found at position 76 , and microsatellite length variation at position 131 in a mononucleotide $\mathrm{T}$ repeat (10/11).

The variable nucleotide positions identify four cytotypes, which show geographically well-defined

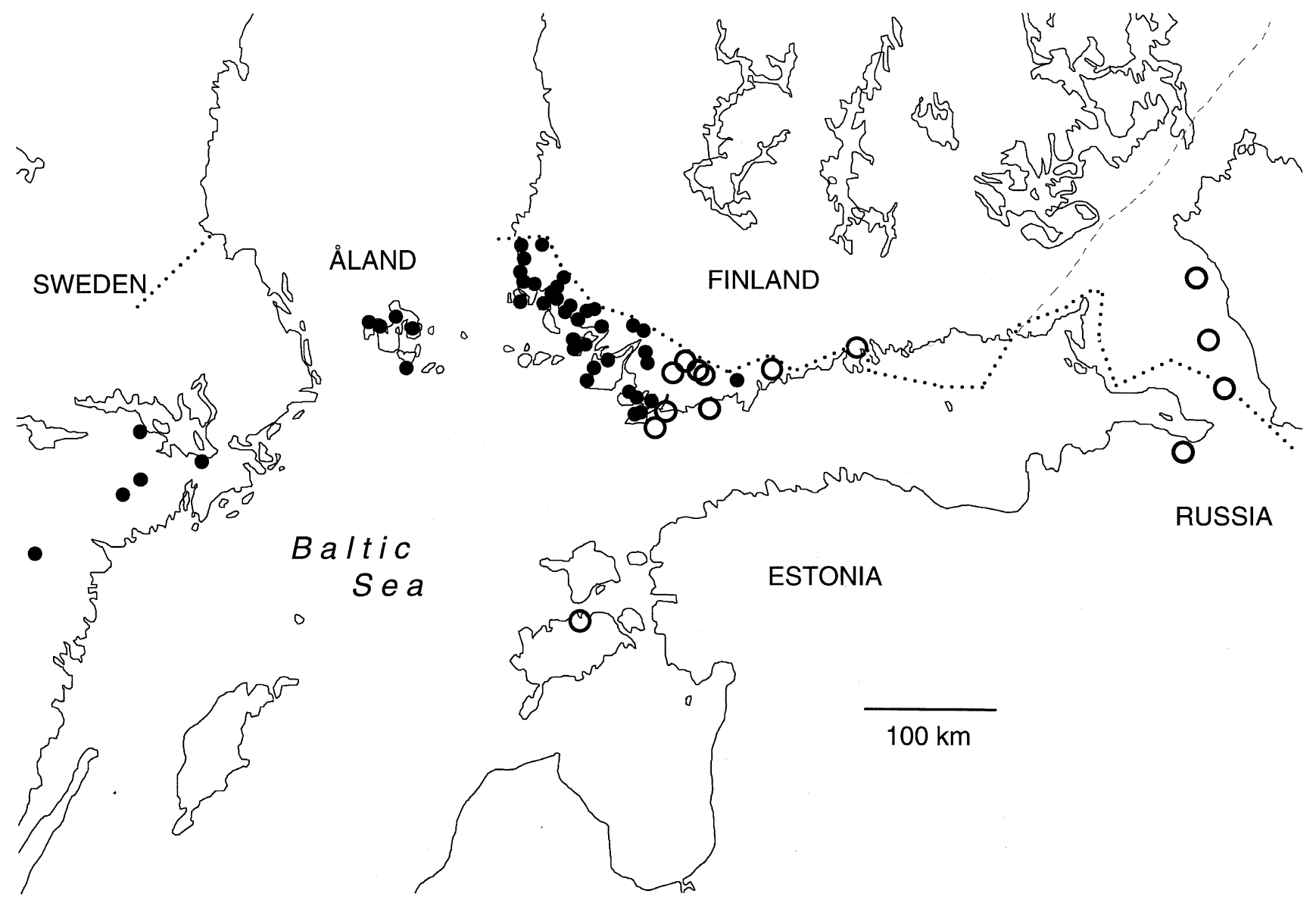

Fig. 2 Distribution of cytotypes in Quercus robur from southern Finland and adjacent regions in Fennoscandia, as determined by restriction analysis which discriminates the eastern cytotype (open circles) from the central type (black dots). Sample sites and sample sizes are listed in Table 2. The dotted line represents the (historical) distribution limit of oak. 
Table 2 Sample details of Fennoscandian Quercus robur given in Fig. 2. For clarity, sites in Fig. 2 are not labelled; the site details for each country represent samples appearing clockwise following the Baltic coastline. The cytotypes given are based on a single nucleotide difference in the $t R N A^{\text {Leul } 1}$ intron as determined by restriction enzyme analysis using $C f o \mathrm{I}$

\begin{tabular}{|c|c|c|}
\hline Site & $\begin{array}{c}\text { Sample } \\
\text { size }\end{array}$ & Cytotype \\
\hline \multicolumn{3}{|l|}{ Sweden } \\
\hline Norsholm & 1 & $\mathrm{~T}$ \\
\hline Årdala & 1 & $\mathrm{~T}$ \\
\hline Gryt & 1 & $\mathrm{~T}$ \\
\hline Strängnäs & 1 & $\mathrm{~T}$ \\
\hline Salem & 2 & $\mathrm{~T}$ \\
\hline \multicolumn{3}{|l|}{ Åland } \\
\hline Eckerö, Skag & 2 & $\mathrm{~T}$ \\
\hline Hammarland, Brändö & 4 & $\mathrm{~T}$ \\
\hline Lemland, Västeränga & 4 & $\mathrm{~T}$ \\
\hline Finström, Bastö & 4 & $\mathrm{~T}$ \\
\hline Sund, Björby & 3 & $\mathrm{~T}$ \\
\hline \multicolumn{3}{|l|}{ Finland } \\
\hline Uusikaupunki, Elkkyinen & 5 & $\mathrm{~T}$ \\
\hline Uusikaupunki, Sundholm & 3 & $\mathrm{~T}$ \\
\hline Laitila, Mustasalo & 5 & $\mathrm{~T}$ \\
\hline Lokalahti, Vartsaari & 2 & $\mathrm{~T}$ \\
\hline Taivassalo, Onnikmaa & 4 & $\mathrm{~T}$ \\
\hline Taivassalo, Orikvuori & 3 & $\mathrm{~T}$ \\
\hline Mynämäki, Kurasmäki & 5 & $\mathrm{~T}$ \\
\hline Mietoinen, Saari & 1 & $\mathrm{~T}$ \\
\hline Kustavi, Elmnäinen & 3 & $\mathrm{~T}$ \\
\hline Askainen, Lempisaari & 3 & $\mathrm{~T}$ \\
\hline Lemu, Luodonmaa & 2 & $\mathrm{~T}$ \\
\hline Lemu, Nyynäinen & 1 & $\mathrm{~T}$ \\
\hline Turku, Muhkurinmäki & 1 & $\mathrm{~T}$ \\
\hline Turku, Ruissalo & 10 & $\mathrm{~T}$ \\
\hline Turku, Katarinedal & 2 & $\mathrm{~T}$ \\
\hline Turku, Kurala & 2 & $\mathrm{~T}$ \\
\hline Lieto, Loukinainen & 4 & $\mathrm{~T}$ \\
\hline Piikkiö, Niemenkulma & 3 & $\mathrm{~T}$ \\
\hline Parainen, Lillnäset & 4 & $\mathrm{~T}$ \\
\hline Parainen, Lenholm & 2 & $\mathrm{~T}$ \\
\hline Parainen, Pexorholm & 4 & $\mathrm{~T}$ \\
\hline Kemiö, Wijk & 2 & $\mathrm{~T}$ \\
\hline Dragsfjärd, Söglö & 2 & $\mathrm{~T}$ \\
\hline Dragsfjärd, Ekhamn & 5 & $\mathrm{~T}$ \\
\hline Halikko, Märy & 4 & $\mathrm{~T}$ \\
\hline Halikko, Vuorelanmäki & 2 & $\mathrm{~T}$ \\
\hline Perniö, Ajo & 1 & $\mathrm{~T}$ \\
\hline Perniö, Kylänmäki & 3 & $\mathrm{~T}$ \\
\hline Bromarv, Solböle & 2 & $\mathrm{~T}$ \\
\hline Bromarv, Framnäs & 5 & $\mathrm{~T}$ \\
\hline Tenhola, Smedsede & 2 & $\mathrm{~T}$ \\
\hline
\end{tabular}

Table 2 Continued

\begin{tabular}{lcc}
\hline Site & $\begin{array}{c}\text { Sample } \\
\text { size }\end{array}$ & Cytotype \\
\hline Hanko, Bengtsår & 4 & $\mathrm{~T}$ \\
Hanko, Söderbonäs & 3 & $\mathrm{~T}$ \\
Tammisaari, Hästö & 5 & $\mathrm{C}$ \\
Tammisaari, Gullö & 3 & $\mathrm{C}$ \\
Kisko, Orijärvi & 1 & $\mathrm{C}$ \\
Karjalohja, Pipola & 4 & $\mathrm{C}$ \\
Lohja, Paavola & 2 & $\mathrm{C}$ \\
Lohja, Ahtiala & 2 & $\mathrm{C}$ \\
Inkoo, Rövass & 2 & $\mathrm{C}$ \\
Kirkkonummi, Vols & 3 & $\mathrm{~T}$ \\
Espoo, Högnäs & 3 & $\mathrm{C}$ \\
Porvoo, Sannäs & 2 & $\mathrm{C}$ \\
Russia & & \\
Otradnoe & 3 & $\mathrm{C}$ \\
Orekhovo & 2 & $\mathrm{C}$ \\
Toksovo & 3 & $\mathrm{C}$ \\
Gostilitsy & 2 & $\mathrm{C}$ \\
Estonia & & $\mathrm{C}$ \\
$\quad$ Saaremaa, Pammana & 2 & \\
\hline
\end{tabular}

and largely distinct distributions in Europe (Table 1, Fig. 1): the eastern $(\mathrm{C}-\mathrm{G} 10)$, the central $(\mathrm{T}-\mathrm{A}$ 11), the western ( $T-G$ 11) and the East Anglian ( $\mathrm{T}+\mathrm{G} 11)$ cytotypes. The East Anglian type was found only in $Q$. robur whereas the other three were found in both Q. robur and Q.petraea. All six outgroup species had $\mathrm{T}-\mathrm{G}$ cytotypes but the microsatellite was variable among them having 9,10 or 11 repeats (Table 3 ).

\section{Restriction site variation in the north}

Of the eight Finnish samples sequenced, the three easterly ones had the eastern cytotype, whereas five trees from south-western Finland were of central type (Table 1, Fig. 1). The $C f o$ I restriction analysis, which discriminates between the eastern type and the others, showed a distinct geographical division among the 166 trees assayed, with a main east/west contact zone in the region of the Salpausselkä ridges. A single deviation from the generally clearcut pattern was seen: the Kirkkonummi samples did not exhibit the eastern restriction phenotype, unlike neighbouring populations. Of the 48 Fennoscandian samples chosen at random and double-digested for the intron, all lacked the duplication.

(C) The Genetical Society of Great Britain, Heredity, 80, 584-593. 
Table 3 Chloroplast cytotypes of Quercus robur, Q. petraea and six outgroup Quercus species, representing three subsections of the genus Quercus. The cytotypes given are based on four variable sites determined by DNA sequencing of the $t R N A^{L e u 1}$ intron and the nontranscribed intergenic spacer between exon 2 of the $t R N A^{\text {Leul }}$ and $t R N A^{\text {Phe }}$ genes. EMBL database accession numbers are given

\begin{tabular}{|c|c|c|c|c|}
\hline \multirow[b]{2}{*}{ Species } & \multirow[b]{2}{*}{ Subsection } & \multirow[b]{2}{*}{ Cytotype } & \multicolumn{2}{|c|}{ EMBL accession no. } \\
\hline & & & Intron & IGS \\
\hline Q. robur $+Q$. petraea & Quercus & $\mathrm{T}-\mathrm{G} 11$ & Z48748 & AJ002167 \\
\hline Q. robur $+\mathcal{Q}$. petraea & Quercus & $\mathrm{T}-\mathrm{A} 11$ & Z48748 & AJ002166 \\
\hline Q. robur $+\mathcal{Q}$. petraea & Quercus & $\mathrm{C}-\mathrm{G} 10$ & Z48748 & AJ002165 \\
\hline Q. robur & Quercus & $\mathrm{T}+\mathrm{G} 11$ & Z48753 & AJ002167 \\
\hline Q. pubescens & Quercus & $\mathrm{T}-\mathrm{G} 11$ & Z48964 & AJ002161 \\
\hline Q. suber & Cerris & $\mathrm{T}-\mathrm{G} 11$ & AJ002058 & AJ002163 \\
\hline Q. cerris & Cerris & $\mathrm{T}-\mathrm{G} 9$ & Z48965 & AJ002164 \\
\hline Q. coccifera & Cerris & $\mathrm{T}-\mathrm{G} 9$ & AJ002060 & AJ002160 \\
\hline Q. wislizenii & Erythrobalanus & $\mathrm{T}-\mathrm{G} 10$ & AJ002059 & AJ002159 \\
\hline Q. imbricaria & Erythrobalanus & $\mathrm{T}-\mathrm{G} 10$ & Z48961 & AJ002162 \\
\hline
\end{tabular}

\section{Discussion}

cpDNA sequences identify three refugial cytotypes in Europe

Previous studies using the $t R N A^{\text {Leul }}$ intron alone recognized two polymorphisms, which identified a primary east-west subdivision across Europe and a local cytotype restricted to East Anglia (Ferris et al., 1993, 1995). Analysis of the nontranscribed intergenic spacer sequence (IGS) between $t R N A^{\text {Leul }}$ and $t R N A^{\text {Phe }}$ detects two additional mutations. A microsatellite variant corroborates the distinction of the eastern cytotype from the others, and a point mutation splits off from the western European population group a central cytotype, distributed geographically between the eastern and western types.

The current distributions of the eastern, central and western cytotypes are readily explained with a late- and postglacial spread of oak from three distinct and differentiated southern refugia. This agrees with the evidence from fossil pollen maps, which indicate separate refugial areas in the north of the Iberian, Apennine and Balkan peninsulae, and northward migration from them starting about 13000 years ago (Huntley \& Birks, 1983).

There is some overlap in the geographical distributions of the cytotypes, but the zonation is still remarkably clear. The weak longitudinal mixing is unexpected in view of the fast northward postglacial spread seen in the pollen maps and indicating efficient dispersal capacity. Under conditions of normal dispersal, such longitudinal genotype distributions are predicted (Hewitt, 1996). Another prominent feature is the coincidence of the cytotype zonation in the two oak species, $Q$. robur and $Q$. petraea; or the independence of the cytotype distribution of the conventional morphological species boundaries. There are no grounds to assume the different cytotypes would have independently arisen or even been fixed in the two species. This feature is most reasonably seen as reflecting an efficient cytoplasmic gene exchange between the two species during or after the refugial isolation (see Ferris et al., 1993). This is conceivable as the two species are known to hybridize readily under suitable conditions (Rushton, 1993). Similar introgressive hybridization and subsequent pollen swamping have been proposed for Eucalyptus (Potts \& Reid, 1988).

Information on the genealogical relationships of the various cytotypes was sought from an outgroup comparison to six further oak species from three subsections of the genus Quercus. These were all identical to the western cytotype at three of the diagnostic sites; at the microsatellite, the outgroup taxa were variable and thus not useful for polarizing character states (Table 3 ). The western $T-G$ type is inferred as being ancestral within the robur-petraea group, but there are no synapomorphisms in the molecular data to allow further resolution of the branching order of the cytotypes.

The geographical context, however, suggests that the change from the western to the East Anglian type was the most recent. Evidently, the duplication distinguishing this cytotype took place postglacially 
during the colonization of Britain (Ferris et al., 1995). Unlike the other three types, the East Anglian cytotype has only been found in $Q$. robur, so far never in $Q$. petraea. This mutation most likely occurred in Q. robur; as no native Q. petraea are found in the East Anglian area, there may have been no natural opportunity for introgression of this cytotype to $Q$. petraea.

On the other hand, there are good grounds to believe that the history of the three main cytotypes is considerably older than the last glaciation. The rate of the chloroplast $r b c L$ gene sequence divergence in the Fagaceae has been estimated at $0.71 \times 10^{-10}$ substitutions/site/year (Frascaria et al., 1993), and the rate at the intron and IGS sequences as 3.5 times faster, $2.5 \times 10^{-10}$ (Gielly \& Taberlet, 1994). In this context, microsatellite length variants, which show generally faster mutational dynamics, may be ignored, and we shall only consider the substitutions observed in the main lineages. Two substitutions were seen in the three lineages within the $875 \mathrm{bp}$ segment examined; the rate calibration above suggests this amount of divergence would be expected if the three lineages diverged simultaneously some $3 \mathrm{Myr}$ ago. It thus seems very unlikely that all the main lineages would have arisen within the last major glacial cycle (c. 100000 years), or even within one of the later ones; more probably, they date back to the early Pleistocene.

During this time the European oak populations will have undergone several range expansions and contractions with the recurring climatic cycles, and lineages once isolated in refugia have repeatedly come into contact and been subject to gene exchange (Hewitt, 1993). It might therefore seem unexpected that a clear-cut diagnostic distinction corresponding to the three main refugial areas remains, particularly as there seem to be no strong barriers to gene flow even at the interspecific level. It is however, possible that the refugial source populations have remained largely unaffected by external gene flow. Fossil pollen data suggest that the climatic deterioration at the end of an interglacial was not accompanied by southward migration of forest tree species (Bennett et al., 1991); rather the onset of cold will generally push succession toward a postclimax such as pine forest, moorland or bog. Pollen data also indicate that temperate tree species have retained populations in the proposed refugial areas through several glacial cycles (Tzedakis, 1993). In these areas, oak populations may thus have remained effectively independent through repeated expansion cycles; this is particularly likely to be true of the chloroplast genome, which appears inefficient in penetrating an existing population.

Our samples were chosen to represent oak stands that most likely can be considered native (with few exceptions). Oak seeds have also frequently been moved around by human activity during several centuries. The geographical pattern of cytotype distribution in more culturally affected localities is therefore not expected to be as clear as that in the present data. Actually, the distinct natural cytotypic zonation presents a tool to confirm cases of longdistance oak translocations, and evidence of such translocations is accumulating (Ferris et al. unpubl. obs.). In our data, the western cytotype in Florence, northern Italy (Fig. 1, site 14) represents a clear deviation from the overall zonation. More samples are, however, needed to see whether this represents a translocation from western Europe, or natural polymorphism in Italian populations.

\section{Independent colonizations of southern Finland}

The range of the newly described central cytotype extends as a relatively narrow band from Italy northward to Switzerland, Germany and through Denmark to central Sweden. From Sweden, it further reaches across the Baltic to the Aland islands and to an outpost in south-western continental Finland. The eastern cytotype, in turn, is now encountered in Estonia and in north-western Russia, as was predictable from the previous records of this type from central eastern Europe (Ferris et al., 1993).

The initial recognition of two cytotypes in Finland led to a more thorough mapping of their distributions in a large proportion of remaining oak stands, using the restriction digest assay. The assay strictly discriminates only between the eastern type and the others; however, the five individuals from southwestern Finland identified directly by sequencing, along with the large-scale cytotype distributions (Fig. 1), make it clear that southern Finland actually represents a contact between the central and eastern oak cytotypes.

The distribution of oak in south-western Finland is generally identified with that of the hemiboreal vegetation zone, and it largely coincides with a similar marginal outpost occurrence of several other plant, fungal and animal species. Many of these taxa are obligately or indirectly dependent on the oak. The problem of oak colonization thus makes an exemplary case of a more general question on the immigration of the biota in this region. Three principal immigration directions may be considered: (i) 
from the west (Sweden) across the Baltic via the Aland islands; (ii) from the south (Estonia) across the Gulf of Finland; (iii) from the east (Russia) through the Karelian isthmus. All these routes have also been suggested to have contributed the southern Finnish oak, entirely or in part (e.g. Ollinmaa, 1952). The view of a western immigration has been dominant, stressing present floral affinities through Åland, and the discontinuity of distribution to the east (Cajander, 1921; Skult, 1965). Yet when considering the history of Finnish oak, it must be noted that at the time of immigration both the climate and geography, and consequently the early oak distribution, were grossly different from the present situation.

Pollen stratigraphy shows that oak spread to southern Scandinavia around $8500 \mathrm{BP}$, when southern Sweden still remained in direct land connection to Denmark (Huntley \& Birks, 1983; Donner, 1995); generally oak pollen was more abundant in these regions than further east. In southern Finland oak appeared about $8000 \mathrm{BP}$, at the beginning of the warm Atlantic chronozone (8000-2500 BP). Oak gradually became more abundant and, as with several other plant taxa, extended its range considerably further north than today. It is regularly found in pollen strata of those times in the lake district $100-200 \mathrm{~km}$ north of the Gulf of Finland and the present distribution limit (e.g. Saarnisto, 1970; Donner, 1995), but later disappears with the southward retreat of the vegetation zones.

On the other hand, at the time of early colonization (>7000 BP), relative sea levels in southern Finland lay 30-70 m higher than today, because of the remaining isostatic depression. Practically the entire current oak range in Finland was submerged, and so were the stepping-stone archipelago and much of central Sweden (e.g. Donner, 1995). Therefore the barriers for early oak dispersal from the west were much greater than seen in the present maps. The sea-distance to be crossed from the west was then some $300 \mathrm{~km}$, whereas that from the south was only $80 \mathrm{~km}$, but no comparable barriers appeared on the potential eastern route. Birds, particularly jays are considered important in transporting oak seeds (acorns), but distances thus transferred are necessarily relatively short and the colonization over seas has probably been by hydrochory (floating acorns). Yet the estimated rates of terrestrial range extension, $350-500 \mathrm{~m} \mathrm{yr}^{-1}$, are remarkably fast (Davis, 1983; Huntley \& Birks, 1983).

Even from the stratigraphical and palaeogeographical evidence, an early colonization from the east across southern Finland would appear most conceivable. The current outpost occurrence of the eastern cytotypes is then plausibly interpreted as an isolated remnant of a formerly continuous range. From the present data on cytotype distribution (Fig. 2), the western cytotypes in Finland would most likely seem of Swedish origin. Although these eastern and western routes are the most likely origins of Finnish oak, other more complex explanations are not yet totally excluded. Dispersal from Estonia across the Gulf of Finland could well have contributed to the eastern outpost occurrence (cf. Ollinmaa, 1952). And actually the data from Estonia so far, one site with the eastern cytotype, cannot definitely exclude an immigration of the western type from the south.

\section{Stable contact zones}

The overall zonation of the oak cytotypes across Europe and across southern Finland appear remarkably distinct. In general the formation and long-term stability of such contact zones, despite the high dispersal capacity of oak, can be understood in the light of the particular dispersal characteristics of oak genomes. The relative dispersal dynamics of cytoplasmic and nuclear genes in the colonization phase are fundamentally different from the situation in an established forest (Hewitt, 1993; Nichols \& Hewitt, 1994). This will result in the retention of stable cytoplasmic demarcation zones at the initial contact sites of two populations expanding from different directions (refugia), a process which has taken place repeatedly in the history of the European oaks.

During range expansion, gene flow to new areas is exclusively by seed, and therefore largely similar for the cytoplasmic and nuclear genomes. Following a contact of effectively continuous populations, the exchange of maternally inherited genes will, however, be effectively impeded. Even though longdistance acorn transfer is not uncommon, the presence of a local acorn pool will effectively swamp any cytoplasmic gene flow to an already occupied territory. This may be viewed as an effect of the highly leptokurtic seed dispersal distribution. As a consequence, the distribution of a cytoplasmic marker will be effectively frozen to the situation at the time of the contact. By contrast, pollen dispersal is less leptokurtic, and nuclear gene exchange between populations is likely to be much more common; the ratio of effective pollen flow to seed flow in oaks has been estimated at 200 (Ennos, 1994). This may rapidly confound the signal of previous history in nuclear markers, and the distri- 
bution of nuclear genetic variation across the observed contact zones (e.g. southern Finland) could actually be very different from the clear pattern seen in cpDNA.

Because of these dynamics, cytoplasmic genomic markers in species like oak will be particularly effective in retaining the historical signal of the colonization phase. On balance, it should be stressed that the cytoplasmic marker distribution may poorly reflect the history and composition of the nuclear genomes of the trees, and therefore may not make a reasonable basis for racial subdivisions. This has been repeatedly evidenced for organellar markers, even in species where the differences in female and male dispersal are less pronounced (e.g. Avise, 1994). The decoupling of the cytotypic and taxonomic identities of the $Q$. robur-Q. petraea complex oaks in central Europe actually makes a particularly illustrative case of this contrast between the historical cytoplasmic signal and the current nuclear genetic composition.

The arguments above, pertaining to contact of populations dispersing over terrestrial habitat, may however, not so directly apply to the history of cytotypic divisions in Finland (Fig. 2). For one thing, as all the current oak sites were still submerged at the time oak arrived in Finland, the observed zone cannot represent a freezing of the actual initial contact site. The current populations may rather represent gradual parallel expansion from the previous more northerly ranges (where oak is now extinct) to new coastal grounds emerging with the postglacial land-uplift. If we still assume that an initial zone arose at the contact of two expanding populations, and the approximate longitudinal (east/ west) position of the zone has been retained in the southward expansion, the implication from the position is that both cytotypes arrived practically simultaneously, and thus early. So if the western type actually came from Sweden, it could not have used the stepping-stone archipelago, but rather must have represented a genuine long-distance dispersal event.

On the other hand, the retention and actual location of the Finnish zone may also have been critically affected by the peculiar geomorphology of the contact area, and by seed dispersal mechanisms peculiar to the coastal environment. From the data at hand, the genetic transition broadly takes place over the Salpausselkäs, a Younger Dryas ice-marginal formation which runs in parallel ridges NE-SW through southern Finland. Particularly in the coastal area, a clear division is made between the samples east and those (north) west of the Hanko peninsular, the extreme projection of
Salpausselkä I to the Baltic. The present ecology of Finnish oak is characteristically coastal, most stands being situated near the shoreline or on outcrops of former islands (Ollinmaa, 1952). Also the range expansion has probably mostly been through colonization of newly emerged ground. Hydrochoric seed dispersal in coastal waters has conceivably been decisive in the colonization process, and consequently to the established cytotype distribution. Throughout the postglacial history and land-uplift process, the Salpausselkä ridges have posed obstacles to such dispersal in the inshore and archipelago zones. Given this mode of colonization, the role of the geological or hydrographical barriers may finally have been more decisive than that of the initial contact site in determining the current Finnish contact zone.

\section{Acknow ledgements}

Financial support from the European Social Fund, the University of Leicester and the Academy of Finland is gratefully acknowledged. We thank Drs H. Haapala, N. Goltsova and G. Konechnaya for providing the Russian samples, Prof. H. Toivonen for some of the Finnish samples, and Drs H. Hyvärinen, C.-A. Haeggström and Y. Vasari for commenting on the manuscript.

\section{References}

AVISE, J. C. 1994. Molecular Markers, Natural History and Evolution. Chapman \& Hall, New York.

BANKS, J. A. AND BIRKY, C. W., JR. 1985. Chloroplast DNA diversity is low in a wild plant, Lupinus texensis. Proc. Natl. Acad. Sci. U.S.A., 82, 6950-6954.

BENNETT, K. D., TZEDAKIS, P. C. AND WILLIS, K. J. 1991. Quaternary refugia of north European trees. $J$. Biogeogr., 18, 103-115.

CAJANDER, A. K. 1921. Zur Kenntnis der Einwanderungswege der Pflanzenarten nach Finnland. Acta Forest. Fenn., 21, 1-16.

DAVIS, M. B. 1983. Quaternary history of deciduous forests of eastern North America and Europe. Ann. Mo. Bot. Gard., 70, 550-563.

DONNER, J. J. 1995. The Quaternary History of Scandinavia. Cambridge University Press, Cambridge.

DOYLE, J. J. AND DOYLE, J. L. 1990. Isolation of plant DNA from fresh tissue. Focus, 12, 13-15.

DOYLE, J. J., DOYLE, J. L., GRACE, J. AND BROWN, A. H. D. 1990. Reproductively isolated polyploid races of Glycine tabacina (Leguminosae) had different chloroplast genome donors. Syst. Bot., 15, 173-181.

ENNOS, R. A. 1994. Estimating the relative rates of pollen and seed migration among plant populations. Heredity, 72, 250-259.

(C) The Genetical Society of Great Britain, Heredity, 80, 584-593. 
FERRIS, C., OLIVER, R. P., DAVY, A. J. AND HEWITT, G. M. 1993. Native oak chloroplasts reveal an ancient divide across Europe. Mol. Ecol., 2, 337-344.

FERRIS, C., OLIVER, R. P., DAVY, A. J. AND HEWITT, G. M. 1995. Using chloroplast DNA to trace postglacial migration routes of oak into Britain. Mol. Ecol., 4, $731-738$.

FRASCARIA, N., MAGGIA, L., MICHAUD, M. AND BOUSQUET, J. 1993. The rbcL gene sequence from chestnut indicates a slow rate of evolution in the Fagaceae. Genome, 36, $668-671$.

GIELLY, L. AND TABERLET, P. 1994. The use of chloroplast DNA to resolve plant phylogenies: noncoding vs. $r b c \mathrm{~L}$ sequences. Mol. Biol. Evol., 11, 769-777.

HewitT, G. M. 1993. Postglacial distribution and species substructure: lessons from pollen, insects and hybrid zones. In: Lees, D.R. \& Edwards, D. (eds) Evolutionary Patterns and Processes, pp. 97-123. Linnean Society Symposium Series 14. Academic Press, London.

HEWITT, G. M. 1996. Some genetic consequences of ice ages, and their roles in divergence and speciation. Biol. J. Linn. Soc., 58, 247-276.

HOWLAND, D. E. 1992. Molecular Variation in Populations of Betula L. PhD Thesis, University of East Anglia.

Hultén, R. 1971. Atlas över växternas utbredning $i$ Norden, 2nd edn. Generalstabens Lithografiska Anstalts Förlag, Stockholm.

Huntley, B. AND BIRKs, H. J. B. 1983. An Atlas of Past and Present Pollen Maps for Europe: 0-13,000 Years Ago. Cambridge University Press, Cambridge.

LAVIN, M., MATHEWS, S. AND Hughes, C. 1992. Chloroplast DNA variation in Gliricidia sepium (Leguminosae): intraspecific phylogeny and tokogeny. Am. J. Bot., 78, 1576-1585.

NICHOLS, R. A. AND HewitT, G. M. 1994. The genetic consequences of long distance pollen dispersal during colonization. Heredity, 72, 312-317.

NOVAK, S. J. AND SOLTIS, P. S. 1991. Intraspecific cpDNA variation in four species of Lomatium (Umbelliferae). Am. J. Bot., 78, 207.

OLlinmaA, P. J. 1952. Jalot lehtipuumme luontaisina ja viljeltyinä. Silva. Fenn., 77, 1-73.

PALMER, J. D. 1987. Chloroplast DNA evolution and biosystematic uses of chloroplast DNA variation. Am. Nat., 130, S6-S29.
PETIT, R. J., KREMER, A. AND WAGNER, D. B. 1993. Geographical structure of chloroplast DNA polymorphisms in European oaks. Theor. Appl. Genet., 87, 122-128.

PETIT, R. J., DEMESURe, B. AND PINEAU, E. 1996. Chloroplast DNA (CpDNA) differentiation at a local and continental scale in European oak species: the importance of historical factors. In: Kremer, A. \& Muhs, H.-J. (eds) Inter- and Intra-specific Variation in European Oaks: Evolutionary Implications and Practical Consequences, pp. 145-164. Offical publication of the European Communities, Luxemburg.

POTTS, B. M. AND REID, J. B. 1988. Hybridization as a dispersal mechanism. Evolution, 42, 1245-1255.

RUSHTON, B. S. 1993. Natural hybridization within the genus Quercus L. Ann. Sci. For, 50, 73s-90s.

SAARNISTO, M. 1970. The late Weichselian and Flandrian history of the Saimaa lake complex. Soc. Sci. Fenn., Comm. Phys.-Math., 37, 1-107.

SEWELL, M. M., PARKS, C. R. AND CHASE, M. W. 1996. Intraspecific chloroplast DNA variation and biogeography of North American Liriodendron L. (Magnoliaceae). Evolution, 50, 1147-1154.

Skult, H. 1965. Quercus robur L. - Tammi. In: Jalas, J. (ed.) Suuri Kasvikirja, 2, pp. 102-107. Otava, Helsinki.

SOlTis, D. E., SOltis, P. S., RANKer, T. A. AND NESS, B. D. 1989. Chloroplast DNA variation in a wild plant, Tolmiea menziesii. Genetics, 121, 819-826.

SOlTIS, D. E., MAYER, M. S., SOlTIS, P. S. AND EDGERTON, M. 1991. Chloroplast DNA variation in Tellima grandiflora (Saxifragaceae). Am. J. Bot., 78, 1379-1390.

SOLTIS, D. E., SOlTIS, P. S. AND MILligAN, B. G. 1992. Intraspecific cpDNA variation: Systematic and phylogenetic implications. In: Soltis, D. E., Soltis, P. S. \& Doyle, J. J. (eds) Molecular Systematics of Plants, pp. 117-150. Chapman \& Hall, New York.

TABERlet, P., GIELly, L., PAUtou, G. AND BOUVET, J. 1991. Universal primers for amplification of three non-coding regions of chloroplast DNA. Plant Mol. Biol., 17, 1105-1109.

TZEDAKIS, P. C. 1993. Long-term tree populations in northwest Greece through multiple Quaternary climatic cycles. Nature, 364, 437-440.

ZANETTO, A. AND KREMER, A. 1995. Geographical structure of gene diversity in Quercus petraea (Matt.) Liebl. I. Monolocus patterns of variation. Heredity, 75, 506-517. 